\title{
Beneficial Uses of ${ }^{241} \mathrm{Am}$
}

\author{
Carolyn A. Mangeng \\ Gary R. Thayer
}

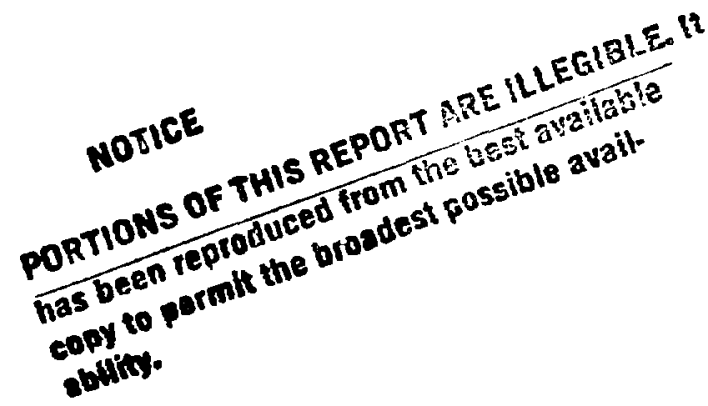

\section{DISCLAIMER}

\begin{abstract}
This report was prepared as an account of work sponsored by an agency of the United States Government. Neither the United States Government nor any agency thereof, nor any of their employees, makes any warranty, express or implied, or assumes any legal liability or responsibility for the accuracy, completeness, or usefulness of any information, apparatus, product, or process disclosed, or represents that its use would not infringe privately owned rights. Reference herein to any specific commercial product, process, or service by trade name, trademark, manufacturer, or otherwise does not necessarily constitute or imply its endorsement, recommendation, or favoring by the United States Government or any agency thereof. The views and opinions of authors expressed herein do not necessarily state or reflect those of the United States Government or any agency thereof.
\end{abstract}




\section{CONTENTS}

ABSTRACT

INTRODUCTION

I. PROPERTIES AND USES OF $241 \mathrm{Am}$.

A. Background .................... 2

B. Use of ${ }^{241} \mathrm{Am}$ as a Feed Material for Irradiation Targets . . . . 6

c. Use of 241 Am in RTGS.................... 11

1. Properties of RTGs ............... 11

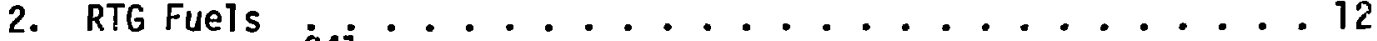

3. Demand for $24 i_{\text {Am }}$ RTGs .................. 16

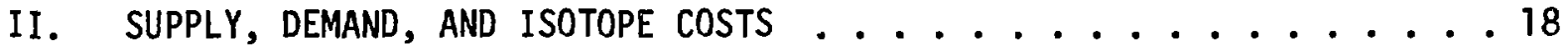

A. Americium Inventory .............. 18

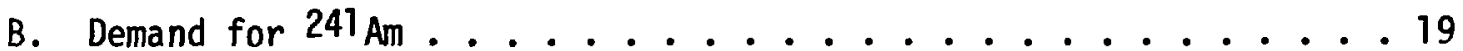

C. Isotope Costs ..................... 21

1. Price of Isotopes i.................. 21

2. Production Cost of $24 i_{\mathrm{Am}} \ldots 21$

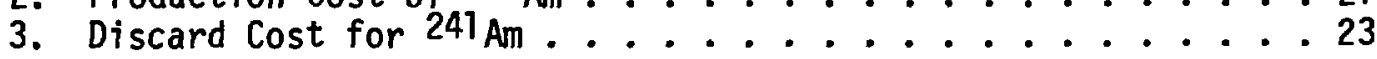

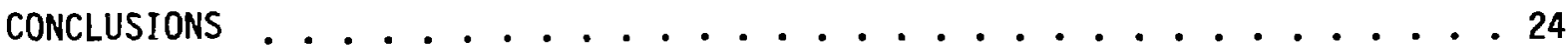

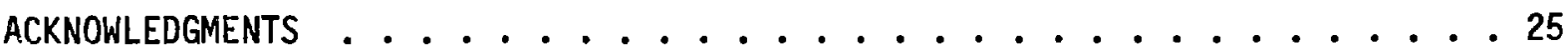

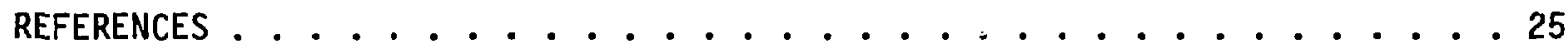


BENEFICIAL USES OF $241_{\text {Am }}$

by

Carolyn A. Mangeng and Gary R. Thayer

ABSTRACT

This report assesses the uses of $241_{\mathrm{Am}}$ and the associated costs and supply. The study shows that 241 Am-fueled radioisotope thermoelectric generators in the range of 1-5 W electrical provide the most promising use of kilogram amounts of this isotope. For medical uses, where purity is essential, irradiation of $241_{\mathrm{Am}}$ can produce $97 \%$ pure $238 \mathrm{Pu}$ at $\$ 21000 / \mathrm{g}$. Using a pyrometallurgical process, $241 \mathrm{Am}$ could he recovered from molten salt extraction (MSE) residues at an estimated incremental cost of $\$ 83 / g$ adjusted to reflect the disposal costs of waste products. This cost of recovery is less than the $\$ 300 / \mathrm{g}$ cost for disposal of the $241_{\mathrm{Am}}$ contained in the MSE residues.

\section{INTRODUCTION}

This study to identify and assess potential beneficial uses of ${ }^{241} \mathrm{Am}$ was initiated at the request of the Department of Energy (DOE) and accomplished through a combination of literature searches, analysis, and interviews with knowledgeable individuals in other divisions at Los Alamos, in the DOE, and in the military and private industry. The findings are presented below in two major sections. In Sec. 1 we investigate the feasibility of using ${ }^{241} \mathrm{Am}$ for radioisotope thermoelectric generators (RTGs), identify and assess applications of ${ }^{241} \mathrm{Am}$ in other systems, and assess the economics and neutronics of producing ${ }^{238} \mathrm{Pu}$ from ${ }^{241} \mathrm{Am}$. In Sec. II we develop an inventory of ${ }^{241}$ Am presently under DOE/Defense Programs coritrol and present demand and cost data. In support of this project, the Plutonium Metal 
Technology group (MST-13) estimated the cost of recovering ${ }^{241}$ Am from the molten salt extraction (MSE) residues at Rocky Flats by means of a pyrometallurgical process and the Nuclear Materials Process Technology group (MST-12) estimated ${ }^{241}$ Am discard costs. To complete the assessment, current and projected demand, supply, and waste-storage costs were examined.

\section{PROPERTIES AND USES OF ${ }^{241}$ Am}

A. Background

Americium-241 is a manmade actinide with a half-life of 432 years. It emits 5.49- and 5.44-MeV alpha particies and a 60-keV gamma ray. All of these can be used for a wide variety of applications. In fact, ${ }^{241}$ Am is such a versatile isotope that a compilation of its major known or suggested uses makes an impressive list (see Table I). A more detailed description of americium uses was compiled by Le Vert and Helminski.?

As shown in Table I, the uses of ${ }^{241} \mathrm{Am}$ can be divided into these general categories:

transmission/absorption

backscatter

$x$-ray excitation

alpha ionization

$(\alpha, n)$ reactions

In addition to the uses presented in Table I, however, we include in this study use of ${ }^{241} \mathrm{Am}$ as a heat source

use of ${ }^{241}$ Am as irradiation material for production of other isotopes

Direct transmission measurements are the basis of mass and thickness gauges used in a variety of fields. The ${ }^{241} \mathrm{Am}$ gamna can be used to characterize 0.5 - to 3 -mm-thick steel sheets, aluminum sheets up to $50 \mathrm{~mm}$ in thickness, plastic sheets in many thicknesses, and plate glass. ${ }^{2}$ Two-component systems can also be resolved such as in determining the mineral content of bones. Applications of alpha transmission are found in vacuum gauges, gas analysis, and very thin-film thickness gauges. ${ }^{2}$

Absorption radiography takes advantage of the soft americium gamma, which offers more precise measurements than the harder gammas of more conventional sources such as ${ }^{60} \mathrm{Co}^{3}$ Examples of this application are also shown in Table I. 
TABLE I

USES OF $241_{\mathrm{Am}}$

\begin{tabular}{|c|c|c|c|}
\hline \multicolumn{2}{|c|}{ Radiation } & \multicolumn{2}{|r|}{ Application } \\
\hline Type & Property & Field/industry & Specific use \\
\hline \multirow[t]{6}{*}{$\mathrm{G}_{3} \mathrm{mma}$} & Transmission & Medicine & $\begin{array}{l}\text { 1. Determine mineral } \\
\text { content of bone } \\
\text { z. Deter mine lipid } \\
\text { content of soft tissue } \\
\text { 3. Evaluate regional } \\
\text { pulmonary vent iation } \\
\text { 4. Determine budy } \\
\text { composition }\end{array}$ \\
\hline & & $\begin{array}{l}\text { Industrial } \\
\text { gauging }\end{array}$ & $\begin{array}{l}\text { 1. Determine thickness } \\
\text { of plate glass } \\
\text { 2. Determine thickness } \\
\text { of metals } \\
\text { 3. Determine thickness } \\
\text { of Al materials } \\
\text { 4. Determine wire } \\
\text { thickness }\end{array}$ \\
\hline & & Soil science & $\begin{array}{l}\text { 1. Measure sol moisture } \\
\text { and density }\end{array}$ \\
\hline & & Hydrology & $\begin{array}{l}\text { 1. Radintian logging of } \\
\text { ground wate } \\
\text { 2. Sediment concentration } \\
\text { gauge }\end{array}$ \\
\hline & & Mineralogy & $\begin{array}{l}\text { 1. Determine bre concen- } \\
\text { tration }\end{array}$ \\
\hline & & Miscellaneous & $\begin{array}{l}\text { 1. Maintain helicopter } \\
\text { nlight formation } \\
\text { 2. Dy ramics of Freon fire } \\
\text { ext inguishers }\end{array}$ \\
\hline \multirow[t]{4}{*}{ Gamma } & Backscatter & Metcorology & $\begin{array}{l}\text { 1. Detcrmine atmospheric } \\
\text { density }\end{array}$ \\
\hline & & Coal & $\begin{array}{l}\text { 1. Defermine ash content } \\
\text { of coal }\end{array}$ \\
\hline & & Coucrete & $\begin{array}{l}\text { 1. Determine cement } \\
\text { in concrete }\end{array}$ \\
\hline & & Mineralogy & $\begin{array}{l}\text { 1. Mineral mining } \\
\text { mischine } \\
\text { 2. Measure iron content } \\
\text { of ores }\end{array}$ \\
\hline \multirow[t]{4}{*}{ Gamma } & $\begin{array}{l}\text { X-ray } \\
\text { excitation } \\
\text { source }\end{array}$ & Mineralogy & $\begin{array}{l}\text { 1. On-stream analyses of } \\
\text { minerals and surries } \\
\text { 2. Analysis of ores }\end{array}$ \\
\hline & & $\begin{array}{l}\text { Analytical } \\
\text { chemistry }\end{array}$ & $\begin{array}{l}\text { 1. Equipment for produc- } \\
\text { tion of } \mathrm{X}_{\text {rays }} \\
\text { 2. Assy high-purtity gold }\end{array}$ \\
\hline & & Medicine & 1. Thysoid diagnosis \\
\hline & & Gauging & $\begin{array}{l}\text { 1. Tile wear measure- } \\
\text { menis } \\
\text { 2. Measure thickness } \\
\text { of metal coatings on stee } \\
\text { 3. Determine paper } \\
\text { weight density }\end{array}$ \\
\hline \multirow[t]{2}{*}{ Gamma } & $\begin{array}{l}\text { Absorption } \\
\text { radiography }\end{array}$ & Medicine & $\begin{array}{l}\text { 1. Determine surface- } \\
\text { to-volume satio of bone }\end{array}$ \\
\hline & & Metallurgy & $\begin{array}{l}\text { 1. Radiography of thin } \\
\text { sheets of } \mathrm{Al} \text { and } \mathrm{Mg}\end{array}$ \\
\hline
\end{tabular}

\begin{tabular}{|c|c|c|c|}
\hline \multicolumn{2}{|c|}{ Radiation } & \multicolumn{2}{|r|}{ Application } \\
\hline Type & Property & Field industry & Specific use \\
\hline & & Aetospacc & $\begin{array}{l}\text { 1. Nondestrustive testing } \\
\text { of steel tubing }\end{array}$ \\
\hline & & Muscellaneous & $\begin{array}{l}\text { 1. Development of radio- } \\
\text { graphic cames a }\end{array}$ \\
\hline \multirow[t]{2}{*}{ Gamma } & $\begin{array}{l}\text { Gamma } \\
\text { source }\end{array}$ & $\begin{array}{l}\text { Radiation } \\
\text { detectors }\end{array}$ & $\begin{array}{l}\text { 1. Calibration of } \\
\text { detectors } \\
\text { 2. Preparation of } \\
\text { lowtevel gammis sourexs }\end{array}$ \\
\hline & & Medicine & $\begin{array}{l}\text { 1. Intracrantal pres- } \\
\text { sure sensor }\end{array}$ \\
\hline \multirow[t]{7}{*}{ Alpha } & Ionization & Gas density & $\begin{array}{l}\text { 1. Jonizatixin gauge } \\
\text { for gas den sities } \\
\text { 2. Determinc planetary } \\
\text { atmospheric density }\end{array}$ \\
\hline & & $\begin{array}{l}\text { Gas chromatog. } \\
\text { raphy }\end{array}$ & 1. Ionization detector \\
\hline & & Building & $\begin{array}{l}\text { 1. Air monditioning } \\
\text { 2. Lightning sods } \\
\text { 3. Smoke-density detector }\end{array}$ \\
\hline & & Wat chmaking & $\begin{array}{l}\text { 1. Preparation of luminous } \\
\text { paints }\end{array}$ \\
\hline & & Alpha detectors & $\begin{array}{l}\text { 1. Calibration of alpha } \\
\text { spectrometer }\end{array}$ \\
\hline & & Gauging & $\begin{array}{l}\text { 1. Determine uniformity } \\
\text { of thin films }\end{array}$ \\
\hline & & Miscellancous & $\begin{array}{l}\text { 1. Measure relative } \\
\text { humidity of air } \\
\text { 2. Spinning disk aet osol } \\
\text { Renerator } \\
\text { 3. Source pacparation }\end{array}$ \\
\hline \multirow[t]{6}{*}{ Alpha } & $\begin{array}{l}\text { Neutron } \\
\text { source }\end{array}$ & Putraleum & 1. Well logging \\
\hline & & Sojl science & $\begin{array}{l}\text { 1. Determine soil density } \\
\text { and moisture content }\end{array}$ \\
\hline & & Moisture meter & $\begin{array}{l}\text { 1. Moistute content } \\
\text { of coke } \\
\text { 2. Moisture content } \\
\text { of concretc }\end{array}$ \\
\hline & & $\begin{array}{l}\text { Activation } \\
\text { ansty }{ }^{* 1 \mathrm{~s}}\end{array}$ & $\begin{array}{l}\text { 1. Determine carban } \\
\text { in ny ash } \\
\text { 2. Determine protern } \\
\text { in grain } \\
\text { 3. Detes mine fluorine } \\
\text { in ores } \\
\text { 4. Determine siltcon } \\
\text { in cast ron } \\
\text { 5. Determine phosphorus } \\
\text { in bone }\end{array}$ \\
\hline & & Neutron counter & $\begin{array}{l}\text { 1. Thermal neutron } \\
\text { counter }\end{array}$ \\
\hline & & $\begin{array}{l}\text { Neutron-scurce } \\
\text { preparation }\end{array}$ & $\begin{array}{l}\text { 1. Preparation of }(a, n) \\
\text { and }(r \cdot n) \text { sources } \\
\text { 2. Preparation of a } \\
241 \mathrm{Am}-\mathrm{Bc}-24^{2} \mathrm{Cm} \text { source }\end{array}$ \\
\hline
\end{tabular}

SOURCE: Wallace W. Schulz, The Chemistry of Americium (Energy Research and Development Administration, Technical Information Center, Springfield, Virginia, 1976), pp. 30-32. 
Backscatter applications are important where only one surface is available or where resolution is affected by the presence of other elements, such as surface coating of a different material. Uses for backscatter measurements are found in many industries to resolve multicomponent systems, such as determining water in soil, ash in coal, iron in ores, and cement in concrete.

The gamma radiation of ${ }^{241} A m$ is of sufficient energy to cause $x$-ray fluorescence in elements from calcium to barium, and their concentration can then be determined from the monitored fluorescence spectra. This use of ${ }^{241}$ Am also has a wide variety of applications, from on-line process control in several industries to determination of wear in floor materials. ${ }^{241} \mathrm{Arn}$ is particularly useful for portable or continuous-measurement devices because it needs no power source to produce $x$ rays and the stray radiation can be kept to a minimum.

The alpha particles of ${ }^{241}$ Am have been used as a means of producing ions, which then may be used to measure a variety of parameters. The most widespread use of ${ }^{241} \mathrm{Am}$ in this mode is in home smoke detectors, although the actual amount of americium used in any one device is very small $(2.7 \mathrm{\mu g})$. Other applications of alpha ionization are static-charge el iminators and humidity measurement equipment.

By far the greatest quantity of ${ }^{241} A m$ is used in neutron sources, which take advantage of the $(\alpha, n)$ reaction induced by the americium alpha particle in low $Z$ elements. Neutron sources are used in a variety of industries, as shown in Table I, to measure density, moisture, and hydrocarbon content. The largest use is in the petroleun industry for well logging. In 1971, neutron well logging was characterized as a $\$ 40$ million/yr industry, ${ }^{2}$ and it is presently estimated at $\$ 60-70 \mathrm{million} / \mathrm{yr}$. * Neutron sources contain up to $20 \mathrm{Ci}$ of ${ }^{241} \mathrm{Am}$, or about $6 \mathrm{~g}$. An interesting new application of a ${ }^{241}$ Am neutron source was recently developed by Texaco, Inc.; it was designed to monitor the salt content of crude oil. The instrument can measure very low concentrations of chloride with good accuracy. ${ }^{4}$

The energy of the ${ }^{241} \mathrm{Am}$ alpha emission can be used in heat sources for RTGs, which convert heat to electrical energy. This application has the

*Information provided by L. Jones, Monsanto Co., Dayton, Ohio, June 20, 1983. 
potential of creating a new market for large quantities (kilograms) of ${ }^{247} \mathrm{Am}$ and is discussed in detail in Sec. I.C.

Finally, ${ }^{241}$ Am can be irradiated to produce other actinide isotopes of special interest. Americium-241 is the feed material for the production of two other isotopes that could be in demand-- ${ }^{242} \mathrm{Cm}$ and "medical-grade" (very high assay) ${ }^{238} \mathrm{Pu}$. Curium-242 is produced by irradiating ${ }^{241} \mathrm{Am}$ in a nuclear reactor. Curium-242 has one of the highest specific powers $(120 \mathrm{~W} / \mathrm{g})$ of any of the commonly considered RTG heat sources. Unfortunately, ${ }^{242} \mathrm{Cm}$ is extremely difficult and inconvenient to handle because of its radiation and short half-iife. Several demonstration ${ }^{242} \mathrm{Cm}$ RTGs were fabricated for the SNAP 11 program but never deployed. A ${ }^{242} \mathrm{Cm}$ RTG would be useful in an application requiring a large amount of power from a physically small source for a short time. Because ${ }^{242} \mathrm{Cm}$ decays to ${ }^{238} \mathrm{Pu}$ (a common heat source for very compact terrestrial and space RTGs), an application initially demanding a large amount of power and then a lower level of power for an extended period of time could be satisfied by a ${ }^{242} \mathrm{Cm}$ RTG. An example of such a use is a satellite that requires a large amount of power during ascent to a stable orbit but has small power requirements for long-term station-keeping and data transmission.

Very high assay ${ }^{238} \mathrm{Pu}$ is of special interest in medical applications. The recent studies with artificial hearts have renewed interest in producing a long-life power source that can be implanted in the body. RTGs have been considered for this power source. The primary concerns with RTG power sources for human implantation are that both the source and the surface radiation must be small. The main candidate for the heat source is very pure ${ }^{238} \mathrm{Pu}$. The normal ${ }^{238} \mathrm{Pu}$ obtained from irradiation of $237_{\mathrm{Np}}$ contains $236 \mathrm{Pu}$, which adds significantly to the external radiation. The typical assay of heat source ${ }^{238} \mathrm{Pu}$ produced from ${ }^{237} \mathrm{~Np}$ is shown in Table II. The indicated concentration of ${ }^{236} \mathrm{Pu}$ is unacceptable for medical purposes because of the gamma radiation emitted from its daughter products. Very pure or "medicalgrade" ${ }^{238} \mathrm{Pu}$ should contain less than $0.3 \mathrm{ppm}{ }^{236} \mathrm{Pu}$. A medical-grade ${ }^{238} \mathrm{Pu}$ consisting of greater than $97 \%{ }^{238} \mathrm{Pu}$ can be produced by first irradiating ${ }^{241} \mathrm{Am}$ to produce ${ }^{242} \mathrm{Cm} .{ }^{242} \mathrm{Cm}$ has a 163 -day half-life and decays solely to ${ }^{238} \mathrm{Pu}$. Thus if the ${ }^{242} \mathrm{Cm}$ is separated shortly after irradiation and allowed to decay, medical-grade plutonium can be separated from the curium and americium mixture. Research at the University of 
TABLE II

ISOTOPE COMPOSITION OF PLUTONIUM FUEL PRODUCED BY IRRADIATION OF $237_{\mathrm{Np}}$

\begin{tabular}{c} 
Pu Isotope \\
\hline 236 \\
238 \\
239 \\
240 \\
241 \\
242
\end{tabular}

\begin{tabular}{c}
$\begin{array}{c}\text { Abundance } \\
\left(w t^{\%} \text { of } P U\right)\end{array}$ \\
\hline 0.0001 \\
80.0 \\
16.3 \\
3.0 \\
0.6 \\
0.1
\end{tabular}

Washington on a heat-source-powered Stirling engine for an artificial heart is currently under way and may result in potential use of ${ }^{238} \mathrm{Pu}$.* B. Use of 241 Am as a Feed Material for Irradiation Targets

We have identified two uses of ${ }^{241} \mathrm{Am}$ as an irradiation target material. The first use is to produce medical-grade ${ }^{238} \mathrm{Pu}$, and the other is to produce ${ }^{242} \mathrm{Cm}$ for use as a heat source in an RTG.

We estimated the cost of medical-grade plutonium assuming a production campaign based on the 1970 work at Oak Ridge National Laboratory (ORNL) to produce ${ }^{242} \mathrm{Cm}$ for the SNAP-11 RTG power source. ${ }^{5,6}$ We assumed ${ }^{241} \mathrm{Am}$ would be fabricated into target pins to be irradiated in the Oak Ridge Research Reactor (ORR). The targets would be irradiated for 120 days for a total effective fluence of $1.2 \times 10^{21}$ neutrons $/ \mathrm{cm}^{2}$. The americium and curium would be separated four weeks after the irradiation. The separation yields were those obtained in the SNAP-11 project. The americium-curium mixture would then be allowed to decay for two years before separating the ${ }^{238} \mathrm{Pu}$.

A two-step chemical separation is necessary primarily to remove the ${ }^{242} \mathrm{Pu}$ impurity that occurs in $15 \%$ of the ${ }^{242}$ Am decays, (see Fig. 1). If the plutonium were separated after a 2-year decay of the irradiated ${ }^{241} \mathrm{Am}$ without the first separation, the plutonium would have the eventual isotopic composition shown in the last column of Table III $\left(15 \%{ }^{242} \mathrm{Pu}\right)$. By first separating the ${ }^{242} \mathrm{Cm}$, the contaminating plutonium isotopes built in during irradiation are removed and only the ${ }^{238} \mathrm{Pu}$ product of ${ }^{242} \mathrm{Cm}$ decay remains.

\footnotetext{
*Information provided by G. L. Tingley, Pacific Northwest Laboratories, Richland, Wash., JuTy 1983.
} 


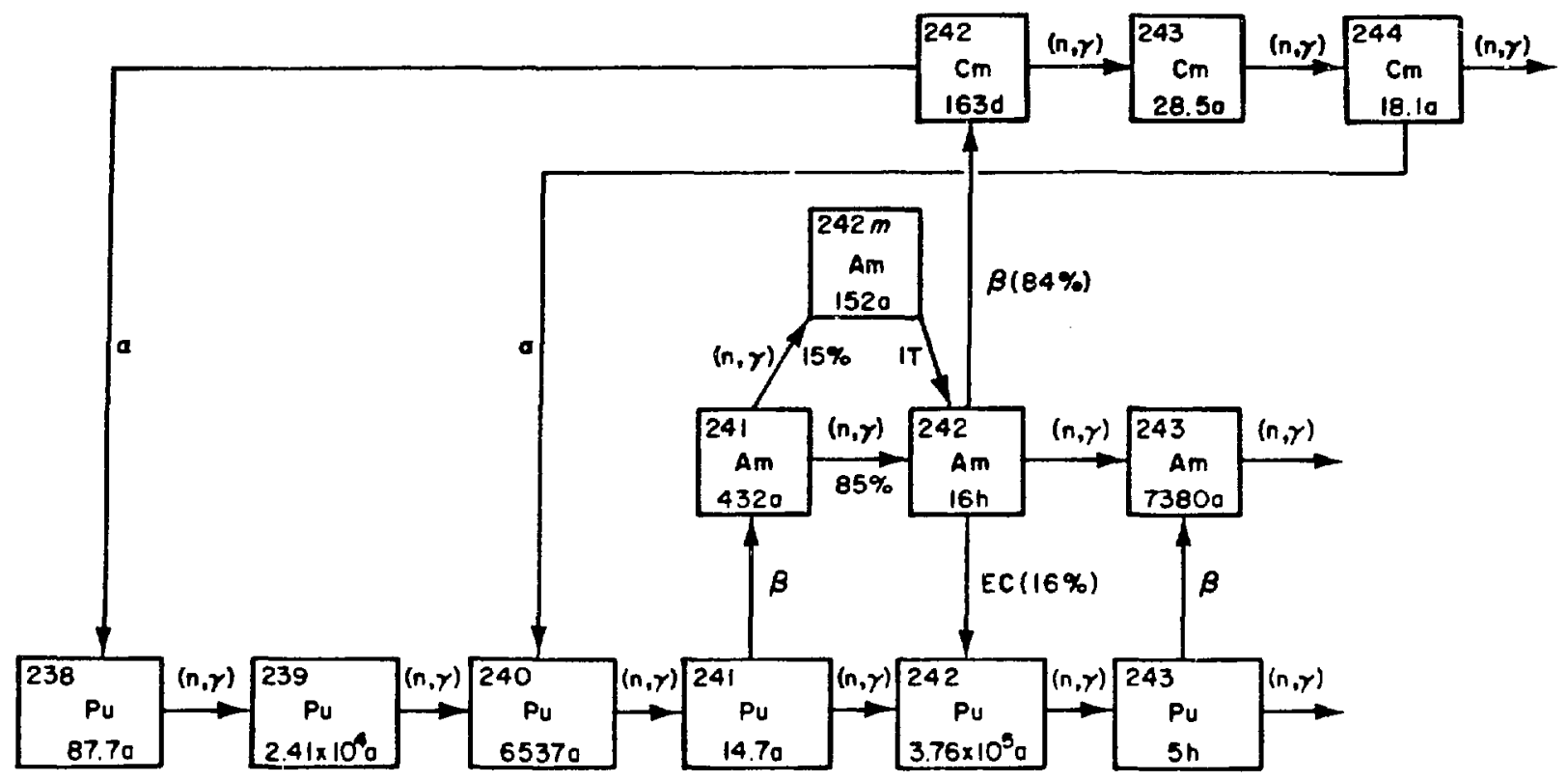

Fig. 1. Neutron irradiation of $241^{\mathrm{Am}}$.

TABLE III

ISOTOPIC CONTENT OF IRRADIATED $241_{\text {Ama }}$

\begin{tabular}{|c|c|c|c|c|c|}
\hline Isotope & $\begin{array}{c}\text { Initial } \\
(\mathrm{g})\end{array}$ & $\begin{array}{l}\text { Di scharged } \\
\text { From Reactor } \\
(g) \\
\end{array}$ & $\begin{array}{l}2 \text { wk after } \\
\text { Discharge } \\
(\mathrm{g}) \\
\end{array}$ & $\begin{array}{c}4 \text { wk after } \\
\text { Discharge } \\
(g) \\
\end{array}$ & $\begin{array}{c}2 \text { yr after } \\
\text { Discharge } \\
\text { (g) }\end{array}$ \\
\hline${ }^{234} U$ & 0 & 0.1 & 0.2 & 0.2 & 5.9 \\
\hline & 0 & 105.5 & 126.3 & 145.9 & 445.7 \\
\hline & 0 & 10.4 & 10.4 & 10.4 & 10.4 \\
\hline & 0 & 1.5 & 1.5 & 1.5 & 1.5 \\
\hline & 0 & 0.8 & 0.8 & 0.8 & 0.7 \\
\hline & 0 & 81.8 & 82.2 & 82.2 & 82.2 \\
\hline & 1000 & 291.4 & 291.4 & 291.4 & 290.5 \\
\hline $242 \pi \mathrm{Am}$ & 0 & 5.1 & 5.1 & 5.1 & 5.0 \\
\hline & 0 & 27.3 & 27.3 & 27.3 & 27.3 \\
\hline${ }^{242} \mathrm{~cm}$ & 0 & 358.2 & 339.5 & 319.8 & 14.3 \\
\hline & 0 & 11.2 & 11.2 & 11.2 & 10.6 \\
\hline${ }^{244} \mathrm{Cm}$ & 0 & 8.2 & 8.2 & 8.2 & 7.6 \\
\hline${ }^{245} \mathrm{Cm}$ & 0 & 0.4 & 0.4 & 0.4 & 0.4 \\
\hline
\end{tabular}

Irradiation time $=120$ days.

Total effective fluence $=1.2 \times 10^{21}$ neutrons $/ \mathrm{cm}^{2}$. Initial ${ }^{241_{A m}}=1 \mathrm{~kg}$. 
Table III gives the isotopic content of the irradiated americium if the initial chemical separation is not performed. This was calculated with the CINDER code. ${ }^{7}$ The flux spectrum was that of a 1 ight water reactor.

We attempted only a rough optimization of the irradiation time because the production location (ORNL) and irradiation facility (ORR) were only used as examples. In addition, we did not have an accurate flux spectrum for the ORR that would allow the calculation of any meaningful optimization. Thus, the costs calculated do not necessarily represent a miniumum cost. However, in view of the other uncertainties in the cost numbers, any irradiation optimization would have little effect on the outcome.

The first step in the chemical separation process is to obtain the curium and americium in the irradiated pins after a 4-week decay. The characteristics of this operation are given in Table IV. ${ }^{6}$ The second step is to separate plutonium after a 2-yr decay. The final product is $97.2 \%$ ${ }^{238} \mathrm{Pu}$ in an overall yield of $40 \%$. The greatest impurity is ${ }^{234} \mathrm{U}$ at $1.3 \%$.

TABLE IV

CHEMICAL SEPARATION OF $242 \mathrm{Cm}$ AND 23BPu

\begin{tabular}{|c|c|c|c|c|c|c|}
\hline Isotope & $\begin{array}{c}\text { Feeda } \\
4 \text { Wk Decay } \\
(\mathrm{g}) \\
\end{array}$ & 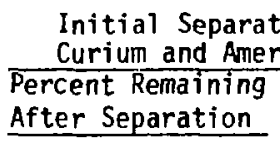 & $\begin{array}{l}\text { on of } \\
\text { cium } \\
\begin{array}{c}\text { Material } \\
(\mathrm{g})\end{array} \\
\end{array}$ & $\begin{array}{c}\text { Feed } \\
2 \text { yr Decay } \\
(\mathrm{g}) \\
\end{array}$ & $\begin{array}{l}\text { Final Separation of } \\
\text { Percent Remaining } \\
\text { After Separation }\end{array}$ & $\begin{array}{l}\text { Plutonium } \\
\text { Material } \\
\text { (g) }\end{array}$ \\
\hline $234 u$ & 0.2 & 1 & 0 & 3.9 & 99 & 3.9 \\
\hline${ }^{238} \mathrm{Pu}$ & 145.9 & 1 & 1.5 & 287.8 & 99 & 284.9 \\
\hline${ }^{239} \mathrm{Pu}$ & 10.4 & 1 & 0.1 & 0.1 & 99 & 0.1 \\
\hline${ }^{240} \mathrm{Pu}$ & 1.5 & 1 & 0 & 0 & 99 & 0 \\
\hline${ }^{241} \mathrm{Pu}$ & 0.8 & 1 & 0 & 0 & 99 & 0 \\
\hline${ }^{242} \mathrm{Pu}$ & 82.2 & 1 & 0.8 & 0.8 & 99 & 0.8 \\
\hline $241 \mathrm{Am}$ & 291.4 & 95 & 276.8 & 276.3 & 1 & 2.8 \\
\hline${ }^{242}$ Am & 5.1 & 95 & 4.8 & 4.7 & 1 & 0 \\
\hline${ }^{243} \mathrm{Am}$ & 27.3 & 95 & 25.9 & 25.9 & 1 & 0.2 \\
\hline${ }^{242} \mathrm{~cm}$ & 319.8 & 95 & 303.8 & 13.6 & 1 & 0.1 \\
\hline${ }^{243} \mathrm{Cm}$ & 11.2 & 95 & 10.6 & 10.0 & 1 & 0.1 \\
\hline${ }^{244} \mathrm{~cm}$ & 8.2 & 95 & 7.8 & 7.2 & 1 & 0.1 \\
\hline${ }^{245} \mathrm{Cm}$ & 0.4 & 95 & 0.4 & 0.4 & 1 & 0 \\
\hline
\end{tabular}

$\overline{\text { assuming } 1 \mathrm{~kg}{ }^{241} \mathrm{Am}}$ irradiated 120 days at total effective fluence of $1.2 \times 10^{21}$ neutrons $/ \mathrm{cm}^{2}$. The total ${ }^{241}$ Am converted equals $708.6 \mathrm{~g}$. 
The only other plutonium isotope that appears in amounts greater than $0.1 \%$ is ${ }^{242} \mathrm{Pu}$ at $0.3 \%$. Americium-241 is present at $1 \%$ and other isotopes at $0.2 \%$.

Table $V$ lists the cost assumptions and calculations for the production of medical-grade plutonium. The total estimated cost is $\$ 21000 / \mathrm{g}$ of ${ }^{238} \mathrm{Pu}$ or $\$ 37500 / W$.

The chemical sepiration costs were obtained by using the experience of the SNAP-11, ${ }^{242} \mathrm{Cm}$ campaign.* We assumed that approximately 1.2 man-weeks are needed to fabricate each ${ }^{241}$ Am source pin containing $3.3 \mathrm{~g}$ of ${ }^{241} \mathrm{Am}$. Nine of these source pins could be irradiated in one position in the ORR reactor. The cost for a year in one ORR position was given as $\$ 200000$.** The chemical separation was assumed to start 21 days after irradiation and would require 2 technicians working 3 shifts a day for 14 days for each batch consisting of 3 pins. We assumed 1 supervisory person would be required per 4 technicians. The separation was assumed to take 2 weeks giving an average cooling time of 4 weeks. The cost of separation of ${ }^{238} \mathrm{Pu}$ after cooling for 2 years was assumed to be approximately $\$ 100 / \mathrm{g}$ of feed material.

For the capital costs, it was assumed that either an existing facility would be used as is or slightly modified for the chemical separation, so no capital cost was included. If a new facility or extensive modification of existing facilities were needed, then there would be a significant capital cost component added to these costs. This capital cost component would be highly dependent on the construction needed, lifetime of the facility, other uses of the facility, and the amount of ${ }^{238} \mathrm{Pu}$ processed by the facility.

A number of other costs were not included because of the difficulity in obtaining any estimate for them. Costs not included were disposal costs for the waste streams of the chemical processing, ${ }^{241}$ Am costs, ${ }^{241}$ Am shipping and storage costs, and ${ }^{238} \mathrm{Pu}$ encapsulation costs. The shipping, storage, and encapsulation costs are highly dependent on the specific circumstances of the use. Americium-241 costs are established by DOE and are dependent on future demand, supply, and processing. They are also dependent on whether the unconverted ${ }^{241} \mathrm{Am}$ is recycled. Waste disposal costs, (see Sec. II.C.3) are difficult to determine and highly dependent upon detailed assumptions.

\footnotetext{
*Information provided by V. C. A. Vaughen, Oak Ridge National Laboratory. JuTy 1983.

**Information provided by E. Lamb, Oak Ridge National Laboratory, JuTy 1983.
} 
TABLE $V$

COSTS FOR MEDICAL GRADE 238PU

\begin{tabular}{|c|c|c|c|c|}
\hline \multicolumn{2}{|c|}{ Item } & $\begin{array}{c}\text { Cost/pin } \\
(\$)\end{array}$ & $\begin{array}{c}\text { Cost } / g \\
241_{\text {Am Feed }} \\
(\$) \\
\end{array}$ & $\begin{array}{l}\text { Cost } / \mathrm{g} \\
238 \mathrm{Pu} \\
(\$) \\
\end{array}$ \\
\hline \multirow[t]{2}{*}{ Pin Fabrication } & Labor & 1680 & 510 & 1790 \\
\hline & Máterials & 168 & 51 & 179 \\
\hline \multirow{3}{*}{$\begin{array}{l}\text { Irradiation } \\
{ }^{242} \mathrm{Cm} \text { Separation }\end{array}$} & & 7300 & 2213 & 7770 \\
\hline & Labor & 9600 & 2910 & 10214 \\
\hline & Materials & 950 & 291 & 1021 \\
\hline \multirow[t]{2}{*}{${ }^{238} \mathrm{Pu}$ Separation } & Labnr & 350 & 106 & 372 \\
\hline & Materials & 35 & 11 & 37 \\
\hline Total & & 20093 & 6092 & 21383 \\
\hline
\end{tabular}

Assumptions

Costs not included

Capital Expenditures

${ }^{241}$ Am Costs

Shipping Costs

Storage Costs

238 Pu Encapsulation Costs

Waste Disposal costs

Manpower costs (including overhead)

Technician \$1 200/wk

Supervisory $\$ 2400 / w k$

Irradiation costs

${ }^{241}$ Am loading per pin

1 ORR position $\$ 200000 / y r$

Number of pins per ORR postion

$3.3 \mathrm{~g}$

Number of pins per ${ }^{242} \mathrm{Cm}$ separation batch

Manpower requirements
Fabrication time per pin
1 tech-wk
0.2 super-wk
$242 \mathrm{Cm}$ separation per batch
16 tech-wk or 2 tech $24 \mathrm{hr} /$ day 14 days
4 super-wk or 1 super per 4 tech
$238 \mathrm{Pu}$ separation per $1 \mathrm{~kg}$ jeed
100 tech-wk
20 super-wk
$10 \%$ of labor costs

Chemical and material coets 
The second use for ${ }^{241} \mathrm{Am}$ as an irradiation target is to produce ${ }^{242} \mathrm{Cm}$ for a high-power-density heat source. The process will be much the same as that above, but the ${ }^{242} \mathrm{Cm}$ will be used immediately instead of allowing it to decay to ${ }^{238} \mathrm{Pu}$. The cost of separatirg ${ }^{242} \mathrm{Cm}$ and ${ }^{241} \mathrm{Am}$ from other irradiation products 4 weeks after irradiation would be $\$ 20200 / \mathrm{g}$ or $\$ 168 / \mathrm{W}$, treating all assumptions as we did above.

A cost optimization can be performed for either of these processes once a site and a chemical separation process are chosen and better estimates of the costs are obtained. Depending on the relative costs for chemical separation, source fabrication, irradiation, and ${ }^{241} \mathrm{Am}$, it might be less expensive to run at high fluxes and convert most of the ${ }^{241} \mathrm{Am}$. This would lower the percentage yield of ${ }^{242} \mathrm{Cm}$ or ${ }^{238} \mathrm{Pu}$ from converted ${ }^{241} \mathrm{Am}$, but each chemical separation batch would yield more ${ }^{242} \mathrm{Cm}$. Thus fewer chemical separation batches would be needed to produce the needed amount of ${ }^{238} \mathrm{Pu}$.

C. Use of $241_{\text {Am }}$ in RTGs

1. Properties of RTGs. Energy produced by the decay of radioactive isotopes is converted from heat to electricity in RTGs. The heat source in RTGs may be fueled by a beta emitter, such as ${ }^{90} \mathrm{Sr}$ or ${ }^{147} \mathrm{Pm}$, or by an arpha emitter, such as ${ }^{238} \mathrm{Pu}$ or ${ }^{241} \mathrm{Am}$. In most RTGs, semiconductor materials are used for this cunversion. A potential difference is creaced across the thermopile that is proportional to the temperature difference between the hot and cold junctions. There are no moving parts. Once operational, the RTG requires no maintenance, additional fuel, or external power source. Its operational lifetime depends primarily on the half-life of the radioisotope used for the heat source. The ${ }^{238_{\mathrm{PU}}}$ RTGS launched on Pioneer in 197? and on the Apollo missions in the 1960s are still operating and may well outlast the operational life of the equipment they power. RTGs operate successfully under very adverse environmental conditions, such as the intense radiation fields encountered in space or harsh surface conditions encountered on other planets or on earth. RTGs can be built to withstand blast effects and are not affected by the electromagnetic pulse of a nuclear explosion. They range in size from a few milliwatts electrical to over 100 watts electrical [W(e)]. The recently developed Multi-Hundred Watt and 
General Purpose Heat Source ${ }^{238} \mathrm{Pu}$ RTGs are modular in design and can deliver several hundred $W(e)$. DOE has funded Teledyne to develop a ${ }^{90} \mathrm{Sr}$ RTG to deliver $500 \mathrm{~W}(\mathrm{e})$.

Because of the properties mentioned above, RTGs have been used in a variety of applications. They have been deployed by the US Coast Guard, Weather Bureau, Navy, and NASA, for example, for a range of uses including use in remote weather stations, terrestrial and undersea buoys, undersea sonic beacons, ground radio beacons, tidal wave warning systems, unmanned seismological stations, submarine cable repeaters, oceanographic instruments and data stations, and remote surveillance stations. RTGs have been used to power cardiac pacemakers as well as to power equipment on satellites in earth orbit and equipment on lunar and planetary spacecraft. Many other applications have been propused from trickle-charging batteries that operate wellhead valves on oil wells to powering artificial hearts.* Clearly, a common feature of these applications is that they involve remote, relatively inaccessible areas where alternative technologies cannot offer comparabie reliability, operational lifetime and flexibility.

There are certain inherent disadvantages to RTGs that should be mentioned. Theremoelectrics only have an overall efficiency of approximately $10 \%$ even when using recently developed selenide materials. The initial cost of the radioisotope fuel is large relative to other more cunventional fuels. In addition, there are costs associated with the design, development, and testing of RTGs. Even after the performance and safety of the RTG design has been assured, each device undergoes rigorous quality assurance testing and documentation with particular attention to the accidental release of its highly radioactive fuel. Nevertheless, these factors do not eliminate the use of the RTGs. There are certain applications where operational requirements are satisfied only by RTGs.

2. RTG Fuels. Most of the terrestrial surface and undersea RTGs have been fueled by ${ }^{90} \mathrm{Sr}$. Strontium-90 has been relatively inexpensive and readily available. Its beta radiation offers less energy per decay than alpha radiation of the actinides, such as ${ }^{238} \mathrm{Pu}$ or ${ }^{241} \mathrm{Am}$, and it requires massive shielding for safe handling and transportation. Plutonium-238 has been

*Information provided by Norbert Elsner, General Atomic Co., La Jolla, Calif., JuTy 1983. 
the preferred isotope for space RTGs because of the mass and volume constraints and because ${ }^{238} \mathrm{Pu}$ has little penetrating radiation in its decay scheme.

Criteria for RTG fuel selection are chemical properties, nature of radiation, specific power, half-life, and cost availability. Table VI presents properties of eight radioisotopes that have been proposed for or used in RTGs developed in the United States. The properties of ${ }^{241}$ Am are also included for comparison.

Desirable chemical properties are good thermal conductivity, chemical stability at operating temperatures $\left(300-1000^{\circ} \mathrm{C}\right)$, a melting point higher than the hot junction of the thermopile, and compatibility with other materials in the RTG.

Chemical compatibility of RTG materials is a major design concern. Compatibility of fuel and liner, fuel and thermopile materials, and thermoelectric components are among the most serious problems. The fluoride fuel form is currently favored for ${ }^{90} \mathrm{Sr}$ heat sources, whereas oxides have been the favored fuel form for the actinides. Extensive compatibility testing with superalloys, noble metals, and refractory metals has been necessary to determine the metal container best suited to the operating conditions of the

TABLE VI

PROPERTIES OF RADIOISOTOPES USED IN HEAT SOURCES

\begin{tabular}{|c|c|c|c|c|c|c|c|c|c|}
\hline & ${ }^{60} \mathrm{Co}$ & $90 . j r$ & $137 \mathrm{Cs}$ & $147 \mathrm{pm}$ & $210 \mathrm{po}$ & $238 \mathrm{Pu}$ & $241_{A m}$ & $242 \mathrm{Cm}$ & $244 \mathrm{~cm}$ \\
\hline Half-life $(y)$ & 5.24 & 28.6 & 30 & 2.62 & 0.38 & 87.7 & 432 & 0.45 & 18.1 \\
\hline Watts/g & 17.8 & 0.93 & 0.42 & 0.33 & 144 & 0.56 & 0.11 & 120 & 2.84 \\
\hline Fuel form & metal & $\mathrm{SrTiO}_{3}$ & $\mathrm{CsC1}$ & $\mathrm{Pm}_{2} \mathrm{O}_{3}$ & GdPo & $\mathrm{PuO}_{2}$ & $\mathrm{AmO}_{2}$ & $\mathrm{Cm}_{2} \mathrm{O}_{3}$ & $\mathrm{Cm}_{2} \mathrm{O}_{3}$ \\
\hline $\begin{array}{l}\text { Power density } \\
\text { (watts/cc) }\end{array}$ & 15.7 & 1.27 & 0.545 & 1.8 & 1260 & 4.0 & 1.12 & 1053 & 27.5 \\
\hline $\begin{array}{l}\text { Type of major } \\
\text { radiation }\end{array}$ & $Y, B$ & $B, X, Y$ & $B, Y, X$ & B & $\alpha, x$ & $\alpha$ & $\alpha, \gamma$ & $\alpha, n$ & $\alpha, n$ \\
\hline $\begin{array}{l}\text { Shielding } \\
\text { requirement }\end{array}$ & heavy & heavy & heavy & minor & minor & minor & minor & minor & moderate \\
\hline $\begin{array}{l}\text { Spontaneous } \\
\text { fission half- } \\
\text { life }(y)\end{array}$ & & & & & & & $4.9 \times 10^{10}$ & $7.2 \times 10^{6}$ & $1.4 \times 10^{7}$ \\
\hline
\end{tabular}

SOURCE: "Characteristics of Radioisotopic Heat Sources," Battelle Pacific Northwest Laboratcries brochure (March 1, 1973). 
heat source. Tetravalent actinide oxides, for example, are very strong oxidizing agents at high temperatures and can degrade certain metal containers. Noble metal alloys, such as platinum and iridium alloys, have been found to contain ${ }^{238} \mathrm{Pu}$ fuel at elevated temperatures. At lower temperatures, control of the Pu-O stoichiometry has been used to surmount problems of oxygen embrittlement of tantalum alloys. Compatibility testing of the ${ }^{244} \mathrm{Cm}$ sesquioxide has indicated that this fuel would be best contained in a platinum-30\%, rhodium-8\%, tunysten (Pt3008) alloy--an extremely oxidation-resistant alloy--at temperatures of $1200-2000^{\circ} \mathrm{C} .^{8}$

Radiation presents many problems. "High energy gamma radiation of some isotopes imposes significant shielding requirements for safe handing and transportation. Alpha radiation from actinides produce $(\alpha, n)$ reactions in low $Z$ elements that may be undesirable in certain applications. This effect can be minimized in oxide fuels, for exampie, by isotope exchange removing the $17_{0}$ and ${ }^{18} 0$ isotopes. A more difficult problem may be the neutron emissions caused by spontaneous fission. These emissions vary widely with the material used. For example, the spontaneous fission neutrons from ${ }^{244} \mathrm{Cm}$. exceed $10^{7} \mathrm{n} / \mathrm{s}-\mathrm{g}$ whereas ${ }^{238} \mathrm{Pu}$ neutron emission is approximately 2200 $\mathrm{n} / \mathrm{s}-\mathrm{g}$ and ${ }^{241}$ Am emission is $1-2 \mathrm{n} / \mathrm{s}-\mathrm{g}$.

High specific power is a very desirable property in an RTG fuel. However, high specific power usually combines with a short half-life, which in turn shortens the RTG's 1 ifetime, causes power-flattening problems, and may create severe handling problems depending on the nature of the decay radiation. Table VII compares ${ }^{238} \mathrm{Pu},{ }^{241} \mathrm{Am}$, and ${ }^{90} \mathrm{Sr}$ properties relevant to their use as heat sources for RTGs. Compared to both ${ }^{90} \mathrm{Sr}$ and ${ }^{238} \mathrm{Pu}$, ${ }^{241}$ Am has a longer half-1ife and a lower power output per gram. Americium-241 produces about $1 / 10$ the power per gram of ${ }^{90} \mathrm{Sr}$ and about $1 / 5$ the power per gram of ${ }^{238} \mathrm{Pu}$. When isotopic purity and fuel form are considered, ${ }^{241} \mathrm{Am}$ has about $25 \%$ of the power density of ${ }^{238}$ pu fuel, $66 \%$ of the power density of the strontium titanate fuel and over $80 \%$ of the power density of the strontium fluoride fuel.

Al though ${ }^{241} \mathrm{Am}$ has only $25 \%$ of the power density of ${ }^{238} \mathrm{Pu}$ and currently costs about 4.5 times as much as ${ }^{238} \mathrm{Pu}$ fuel in terms of dollars per watt, ${ }^{241} \mathrm{Am}$ does have an advantage over plutonium in not being classified as a special nuclear material. Licensing and potential foreign use are therefore simplified. 
TABLE VII

COMPARISON OF $238 \mathrm{Pu}, 241 \mathrm{Am}$, AND $90 \mathrm{Sr}$ CHARACTERISTICS

\begin{tabular}{|c|c|c|c|c|c|c|c|c|c|c|}
\hline & $\begin{array}{l}\text { Specific } \\
\text { Power } \\
\text { (W/g) }\end{array}$ & $\begin{array}{l}\text { Half- } \\
\text { Life } \\
\text { (yr) }\end{array}$ & $\begin{array}{c}\text { Curies/ } \\
\text { Gram } \\
\end{array}$ & $\begin{array}{l}\text { Cost/ } \\
\text { Gram }\end{array}$ & $\begin{array}{l}\text { Fuel } \\
\text { Form }\end{array}$ & $\begin{array}{c}\text { Fuel } \\
\text { Density }\end{array}$ & $\begin{array}{c}\text { Isotopic } \\
\text { Purity } \\
(\mathscr{x}) \\
\end{array}$ & $\begin{array}{c}\text { Fuel } \\
\text { Specific } \\
\text { Power } \\
(W / g) \\
\end{array}$ & $\begin{array}{l}\text { Fuel Power } \\
\text { Density } \\
(\mathrm{H} / \mathrm{cm} 3) \\
\end{array}$ & $\begin{array}{c}\text { Relative } \\
\text { Cost } / \\
\text { Watt } \\
\end{array}$ \\
\hline${ }^{238} \mathrm{Pu}$ & 0.56 & 87.7 & 17.00 & $\$ 1800$ & $\mathrm{PuO}_{2}$ & 11.46 & 80 & 0.39 & 4.47 & 274 \\
\hline${ }^{241} \mathrm{Am}$ & 0.11 & 432.0 & 3.43 & $\$ 1400$ & $\mathrm{AmO}_{2}$ & 11.68 & 99 & 0.096 & 1.12 & 848 \\
\hline${ }^{90} s r$ & 0.93 & 28.6 & 139. & $\$ 14$ & $\mathrm{SrF}_{2}$ & 4.24 & 61 & 0.40 & 1.70 & 1 \\
\hline & & & & & $\mathrm{SrTiO}_{3}$ & 5.03 & 56 & 0.25 & 1.27 & 1 \\
\hline
\end{tabular}

SOURCES: Roberta Shor, R. H. Lafferty, Jr., and P. S. Baker "90Sr Heat Sources," Isotopes and Radiation Technology $\underline{8}$ (3) 260-286 (Spring 1971).

Information provided by Paul Dick, Teledyne Energy Systems, Timonium Md., February 4, 1983.

Information provided by Charles Ottinger, Superintendent of Isotope Distribution, Oak Ridge National Laboratory.

Handbook of Chemistry and Physics, 61 st ed. (CRC Press, Boca Raton, Florida, 1980-1981).

As Table VII indicates, ${ }^{241} \mathrm{Am}$ is presently more expensive than either ${ }^{90} \mathrm{Sr}$ or ${ }^{238} \mathrm{Pu}$ in terms of cost/watt. In order to be competitive with ${ }^{238} \mathrm{Pu}$, the price of ${ }^{241} \mathrm{Am}$ would have to fall from $\$ 1400 / \mathrm{g}$ to $\$ 353 / \mathrm{g}$. In the case of ${ }^{90} \mathrm{Sr}$ the cost of shielding should be taken into account to make a similar cost comparison.

Table VIII presents a breakdown of the typical costs for production of a ${ }^{90} \mathrm{Sr}$ RTG of $60 \mathrm{~W}(\mathrm{e})$. Shielding costs are approximately $10 \%$ of the overall manufacturing costs. For a 1 W(e) RTG, with a selling price of $\$ 100000$,

\section{TABLE VIII}

MANUFACTURING COSTS OF $90 \mathrm{Sr}$ RTG

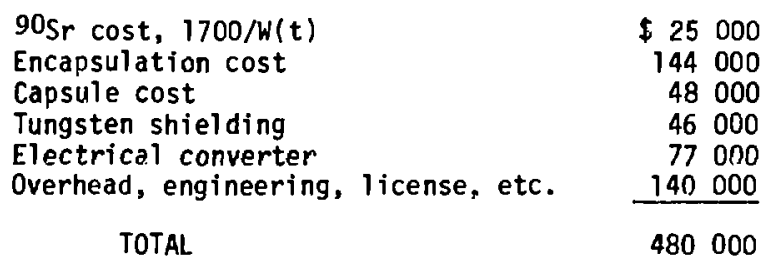


shielding cost would approach $\$ 10000$. Assuming the same conversion efficiency as indicated for the $60 \mathrm{~W}(\mathrm{e}) \mathrm{RTG}$, the fuel and shielding costs would be over $\$ 10400$ for ${ }^{90} \mathrm{Sr}$ from which a competitive price for ${ }^{241} \mathrm{Am}$ can be inferred to be approximately $\$ 42 / g$. If the projected future ${ }^{90} \mathrm{Sr}$ recovery costs are used, then the competitive price increases to $\$ 60 / \mathrm{g} .{ }^{9}$

The primary advantage of ${ }^{241} \mathrm{Am}$ over ${ }^{90} \mathrm{Sr}$ is that only minor shielding is needed for ${ }^{241} \mathrm{Am}$ whereas considerable shielding is needed for ${ }^{90} \mathrm{Sr}$. This additional shielding is an added cost in the manufacture of the heat source and contributes a significant amount of weight and volume to the heat source. Thus, a complete RTG unit using a ${ }^{90} \mathrm{Sr}$ heat source would be considerably larger and heavier than a unit of comparable power using a ${ }^{241}$ Am source.

Other considerations potentially detract from the use of ${ }^{241} \mathrm{Am}$ in RTGs. Very little metallurgical research has been done to test the compatibility of ${ }^{241}$ Am with other materials. Heat transfer could be a problem and represent a size limitation for ${ }^{241}$ Am RTGs. Furthermore, several years of development and testing would be needed to produce and certify a ${ }^{241}$ Am RTG. However, a great deal of research has been done with actinides, and the extensive knowledge and manufacturing experience with ${ }^{238} \mathrm{Pu}$ RTGs would greatly reduce the effort required to produce an "off the shelf" 241 Am RTG.

3. Demand for ${ }^{247}$ Am RTGs. Taking all of these considerations into account, ${ }^{241} \mathrm{Am}$ appears to be an attractive isotope for heat sources in small RTGs of less than $50 \mathrm{~W}(\mathrm{e})$. We have identified several potential users and interviewed people associated with RTG production who expressed the feeling that demand for RTGs will increase radically.* A demonstration $500 \mathrm{~W}(\mathrm{e})$ RTG is being developed and inquiries are being made as to its possible uses in the military. DOD has ordered four 5-watt RTGs for classified uses and more orders are expected. $\star \star$ Another DoD project in the Navy will use acoustic sensors connected by fiber optic cables, each needing its own power source of

\footnotetext{
*Information provided by G. L. Tingley, Pacific Northwest Laboratories, Richland, Wash,, July 1983 and by Norbert Elsner, General Atomic, La Joila, Calif., JuTy 1983.

** Information provided by Robert Brouns, US Department of Energy, Washington, DC, July 1983.
} 
about 1 watt.* The short-term demand for this application is projected to be for 50-100 1-watt power sources. This application would be ideal for RTGs and possibly for ${ }^{241} \mathrm{Am}$. The Air Force has expressed a strong interest in small $(<20$ W) RTGs for upgrading the power supply at remote unmanned installations. $* *$ The survivability, reliability, and long operational life are crucial characteristics of RTGs for these applications. The Air Force furthermore anticipates a very large need that could well exceed the 1.7 megawatts of ${ }^{90} \mathrm{Sr}$ expected to be available by the year 2000 and enthusiastically welcomes the prospect of an alternative heat source such as ${ }^{241} \mathrm{Am}$.

Potential applications of RTGs in the civilian market are primarily in the oil industry. 0 il wells are being drilled farther offshore, in deeper water, and in more hostile environments. On-site, routine monitoring and operation is getting more difficult and expensive, and therefore remote operation and monitoring is becoming more attractive. RTG uses have been hypothesized to power oil well monitoring instruments and to transmit the data to a central facility. Also, RTGs could be used to trickle-charge batteries that provide power for infrequent mechanical operations. One such application was mentioned earlier--opening and closing valves on the wellhead. Although RTGs are not presently used for any of these applications, there is interest in the oil industry in RTGs as power sources for these remote operations.

If demand for RTGs does increase, as some of the individuals we interviewed expect it will, and a ${ }^{241}$ Am RTG is developed, then availability of isotopes for heat sources will become an important consideration. Presently there are approximately $100 \mathrm{~kW}$ of ${ }^{90} \mathrm{Sr}$ stored at Pacific Northwest Laboratories as encapsulated $\mathrm{SrF}_{2}$. This quantity is equivalent to approximately $3500 \mathrm{~W}(\mathrm{e})$ in RTGs and is readily available for use. Currently about 10-20 RTGs, or about a maximum of $500 \mathrm{~W}(\mathrm{e})$, are produced per year in the US.t A continuation of the present demand would make it difficult to justify developing another RTG material, but a significant increase in demand

*Information provided by George Hetland, Naval Research Laboratory, Washington, DC, July 1983.

**Information provided by Stephen Hathaway, Energy Group, Air Force Engineering and Services Center, Tyndall Air Force Base, Florida, August 1983.

tInformation provided by John McGrew, Teledyne Energy Systems, Timonium, Md., July 1983. 
would quickly deplete isotope reserves. For military applications, ${ }^{241}$ Am might be "loaned" at no cost to DoD as ${ }^{238} \mathrm{Pu}$ has been in the past, thus giving ${ }^{241} \mathrm{Am}$ a significant cost advantage over ${ }^{30} \mathrm{Sr}$. (If both isotopes were "free," the use of ${ }^{90} \mathrm{Sr}$ would still entail the added expense of shielding.) For commercial applications, the cost of ${ }^{241}$ Am would have to drop considerably before its use could be viewed as an alternative to ${ }^{90} \mathrm{Sr}$, and sirilarly its availability would have to be eisured by DOE before the private sector would risk such an investment (see Sec. II.B below).

II. SUPPLY, DEMAND, AND ISOTOPE COSTS

A. Americium Inventory

Estimates of ${ }^{241} \mathrm{Am}$ currently in DOE/DP control and in commercial spent fuel are presented below in Table IX. Small quantities of ${ }^{241}$ Am held at various National Laboratories for ongoing research programs were not included in this inventory.

The largest quantity of recoverable ${ }^{241}$ Am in D0E/DP control is at Rocky Flats, where it is stored as a by-product of weapons-grade plutonium recovery. The MSE residues contain approximately 4-5\% plutonium and 0.3-0.4\% ${ }^{241} \mathrm{Am}$, which is the decay product of ${ }^{241} \mathrm{Pu}$ present in the weapons-grade plutonium. Present facilities to recover plutonium from these residues are inadequate, and only a very small fraction of the plutonium is recovered annually by means of an aqueous process.

Significant quantities of ${ }^{241}$ Am are currently siored at Hanford in the form of high-level wastes. This ${ }^{241} \mathrm{Am}$ is not considered to be recoverable. At Savannah River, $572 \mathrm{~g}$ are stored underground as liquid, high-level waste, and another $18 \mathrm{~g}$ are stored as solid, retrievable waste.

The ${ }^{241}$ Am at Los Alamos is currently being recovered by an aqueous process and shipped to Oak Ridge as $\mathrm{AmO}_{2}$ for sale. The recovery of $1000-2000 \mathrm{~g} / \mathrm{yr}$ of ${ }^{241} \mathrm{Am}$ is part of the Cermet Grade Plutonium Dioxide Program at Los Alamos.

Oak Ridge is the repository for al1 ${ }^{241}$ Am sold by DOE. The inventory fluctuates with supply and demand and is expected to grow to about $2000 \mathrm{~g}$ by the end of this year and to more than $5000 \mathrm{~g}$ by the end of 1985. Oak Ridge has the capacity to store up to $30 \mathrm{~kg}$ of ${ }^{241} \mathrm{Am}$.

An estimate of the ${ }^{241}$ Am present in commercial spent fuel is provided in Table IX for comparison to the DOE inventory of ${ }^{241} \mathrm{Am}$. This amount is 
TABLE IX

AMERICIUM-241 INVENTORY

\begin{tabular}{|c|c|c|c|c|}
\hline Site & $\begin{array}{l}\text { Estimated } \\
\text { Inventory } \\
\text { (kg) } \\
\end{array}$ & Chemical Form & $\begin{array}{l}\text { Recent Average } \\
\text { Annual Recovery } \\
\text { or Sales of Am/yr }\end{array}$ & Reference \\
\hline Rocky Flats & $76.0^{a}$ & $\begin{array}{l}\text { Molten salt } \\
\text { extraction residues }\end{array}$ & $200 \mathrm{~g}$ & John Holst \\
\hline Los Alamos & 5.615 & $\begin{array}{l}\text { By-products of FFTF } \\
\text { oxide production }\end{array}$ & $1000-2050 \mathrm{~g}$ & Tom Blum \\
\hline Hanford & $15.6 \mathrm{C}$ & $\begin{array}{l}\text { High-level PUREX } \\
\text { waste }\end{array}$ & $\begin{array}{l}\text { Am recovery facility } \\
\text { shut down in } 1976\end{array}$ & Mike Larson \\
\hline Savannah River & 0.590 & High-level waste & $\begin{array}{l}\text { Multipurpose processing } \\
\text { facility on standby } \\
\text { since } 1981 \text {. Previous } \\
241 \text { Am metal production } \\
\text { (shipped to Dak Ridge): } \\
\text { FY78 } 1.1 \mathrm{~kg} \\
\text { FY79 } 4.78 \mathrm{~kg} \\
\text { FY80 } 1.77 \mathrm{~kg} \\
\text { FYB1 } 0.23 \mathrm{~kg} \\
\quad 7.88 \mathrm{~kg}\end{array}$ & $\begin{array}{l}\text { Mike } 0^{\prime} \text { Rear/ } \\
\text { Tom Ridout }\end{array}$ \\
\hline Oak Ridge & $0.804^{d}$ & $\mathrm{AmO}_{2}$ & $1000-2000 \mathrm{~g}$ & Charles Ottinger \\
\hline $\begin{array}{l}\text { Commercial } \\
\text { Spent Fuel }\end{array}$ & 1160.0 & Clad fuel pins & - & DDE \\
\hline
\end{tabular}

anventory increasing at a rate of approximately $6 \mathrm{~kg} / \mathrm{yr}$.

bCermet grade plutonium dioxide.

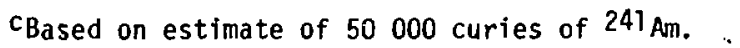

dThis January $1,198 \mathrm{j}$, estimate does not reflect projected sales or FY 83 production of approximately $2000 \mathrm{~g}$ at Los Alamos National Laboratory.

"Department of Energy Plan for Recovery and Utilization of Nuclear Byproducts from Defense Wastes," DOE report DOE/DP-0013, Vo1. 2, P. B.32 (August 1983).

approximately equivalent to $5 \%$ of the $\mathrm{kW}$ of ${ }^{90} \mathrm{Sr}$ present in commercial spent fuel and $20 \%$ of the $\mathrm{kW}$ potential of ${ }^{237} \mathrm{~Np}$ (feed isotope for production of ${ }^{238} \mathrm{Pu}$ ). Of course, the amount of ${ }^{241} \mathrm{Am}$ recovered would depend upon the age of the fuel, the amount of fuel recycling, the type of recovery process, and ultimately on the decision to resume commercial fuel reprocessing in this country.

B. Demand for ${ }^{241} \mathrm{Am}$

The current demand for ${ }^{241} \mathrm{Am}$ is illustrated by recent and projected Dak Ridge sales shown in Table $X$. Historical sales figures indicate some 
TABLE $X$

ANNUAL 241 Am SALES FROM OAK RIDGE (IN GRAMS)

\begin{tabular}{l} 
Fiscal Year. \\
\hline 78 \\
79 \\
80 \\
81 \\
82 \\
83 (projected) \\
84 (projected) \\
85 (projected)
\end{tabular}

\begin{tabular}{r} 
Domestic \\
\hline 1366.4 \\
2667.5 \\
2650.5 \\
1616.2 \\
2603.0 \\
650.0 \\
500.0
\end{tabular}

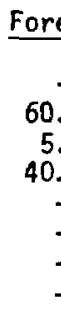

\begin{tabular}{|c|c|c|}
\hline reign & DOE & Total \\
\hline - & - & 1366.4 \\
\hline 0.0 & 22.1 & 2740.6 \\
\hline $\begin{array}{l}5.3 \\
0.0\end{array}$ & 0.2 & 2656.0 \\
\hline & 300.2 & $\begin{array}{l}1659.4 \\
2703.4\end{array}$ \\
\hline - & - & 650.0 \\
\hline & - & 500.0 \\
\hline- & - & 500.0 \\
\hline
\end{tabular}

a Information provided by C. L. Ottinger, Superintendent of Isotope Distribution, Oak Ridge National Laboratory, July 15, 1983.

fluctuation in the domestic and foreign demand; however, an average of $2200 \mathrm{~g}$ has been sold annually from 1978-1982. A very small amount $(5 \mathrm{~g})$ of the ${ }^{241}$ Am sold is used in the manufacture of smoke detectors, but most of the americium has been sold to a handful of companies that manufacture neutron sources for use primarily by the petroleum industry for well logging. Thus, the demand for ${ }^{241}$ Am is currently tied very closely to world crude oil production.

As the supply of oil exceeds demand, crude oil production falls and the need for either exploratory drilling or enhanced production from old wells declines. The need for new neutron sources also falls with this decline. World crude oil production fell to a 10-yr low in 1982, and in the US, drilling was severely curtailed. ${ }^{10}$ Deepwater exploration has also dropped off. ${ }^{11}$ World crude oil production is not forecasted to pick up again for at least another year. ${ }^{10}$

The projected Oak Ridge sales reflect the relationship between the world oil situation and ${ }^{241} \mathrm{Am}$ demand. Market analysis conducted by 0ak Ridge further indicates that demand will not increase significantly in the future, or at least through FY85. It should be noted that this market analysis did not entail any effort to identify new uses or markets.

Even if the world oil situation changes and revives the demand for ${ }^{241}$ Am neutron sources, it is not expected that manufacture of neutron sources alone could significantly boost demand above historical levels, considering the very long half-1ife of ${ }^{241} \mathrm{Am}$ (432 years) and the small 
quantities required for new sources $(6 \mathrm{~g})$. There is essentially no obsolescence to consider.

Therefore, in the absence of any new markets for ${ }^{241} \mathrm{Am}$, future demand should range from $1000-3000 \mathrm{~g}$ annually in the post-1985 period. If new markets for existing uses arise--new markets for neutron sources, for example--the demand could increase by as much as $2000 \mathrm{~g}$ annually. If new uses are developed--in RTGs, for exampie--then demand could increase by many thousands of grams annually. This demand, however, would be very dependent upon current production rates and/or the commitment to increase production rates. Historically, isotope users have been reluctant to invest in new applications until they are assured of isotope availability. ${ }^{12,13}$ The demand for ${ }^{241} \mathrm{Am}$ for use in RTGs specifically would depend on the several considerations presented earlier plus perceived long-term availability of the isotope.

C. Isotope Costs

1. Price of Isotopes. Radioisotopes produced by DOE contractors may be sold through the Cak Ridge Isotope Sales Pool to the private sector, or through special DOE arrangements to other federal agencies such as DOD or NASA. Prices listed in Table XI below for ${ }^{238} \mathrm{Pu}, \star{ }^{241} \mathrm{Am}$, $\star$ and ${ }^{90} \mathrm{Sr}$ are the currently designated prices for sale to the private sector.

These prices, of course, reflect current production costs and also include other cost components such as depreciation, costs of distribution, DOE overhead, and other adjustments. The Federal Register notice of the September $1981{ }^{238} \mathrm{Pu}$ price increase specifically stated that these prices do not recover full production costs.

Historically, ${ }^{238} \mathrm{Pu}$ has been sold to NASA at far lower costs than the private sector costs shown above. Used as the heat source in RTGs for the space program, ${ }^{238} \mathrm{Pu}$ was sold at $\$ 650 / \mathrm{W}$, which is approximately $\$ 360 / \mathrm{g}$ or $20 \%$ of the private sector cost.

2. Production cost of ${ }^{241} \mathrm{Am}$. At the present time all ${ }^{241} \mathrm{Am}$ sold through Oak Ridge is received from Los Alamos National Laboratory.

*Plutonium costs are from 46 F.R. 46155, Sept. 17, 1981.

$\star \star$ Cost information for ${ }^{241} \mathrm{Am}$ was provided by C. L. Ottinger, Oak Ridge Isotope Sales, Oak Ridge, Tenn. 
TABLE XI

CURRENT SALES PRICES OF 238Pu, 241 AT, AND 90Sr

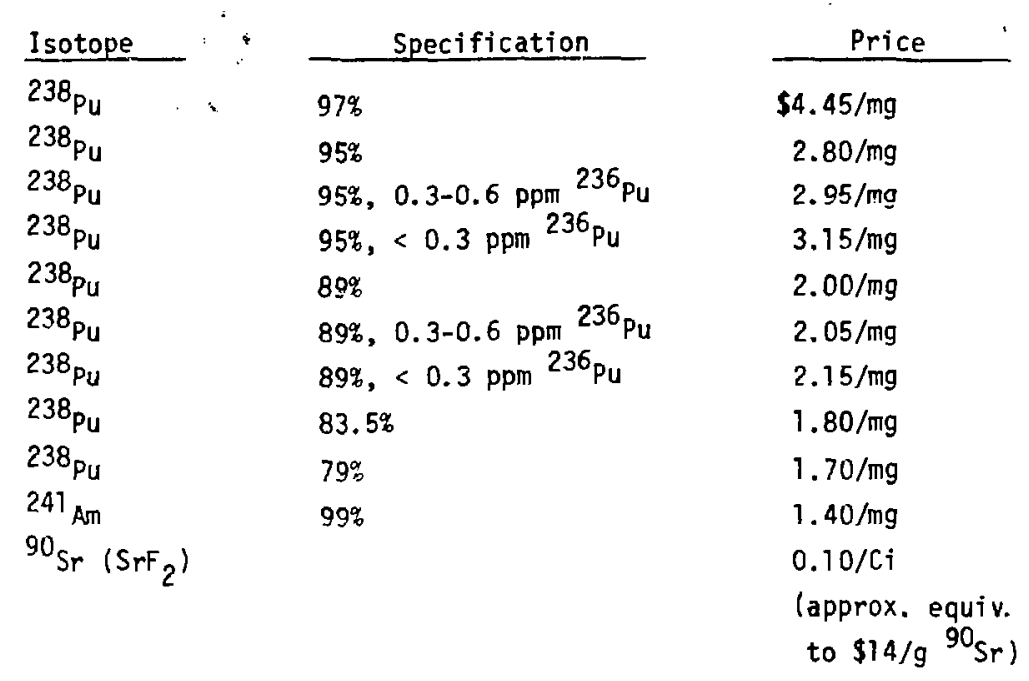

Americium-241 recovery is part of the Los Alamos Cermet Grade Plutonium Dioxide Program. Approximately $2000 \mathrm{~g} / \mathrm{yr}$ of ${ }^{241} \mathrm{Am}$ are separated from the feed materials by means of an aqueous process and prepared as the oxide $\left(\mathrm{AmO}_{2}\right)$ for storage at Oak Ridge. The current estimated costs of production are approximately $\$ 750 / \mathrm{g}$ and are figured into the current Dak Ridge sales price of $\$ 1400 / \mathrm{g}$ *

Los $A 1$ amos has proposed a pyrometallurgical process to recover plutonium from MSE residues at Rocky Flats whereby a significant quantity of ${ }^{241} \mathrm{Am}$ contained in the MSE salt could also be recovered. Initial experiments have obtained two metal products and a salt residue from the process: one metal product contains about $94 \%$ of the feed plutonium and the other, a calcium metal concentrate, contains $6 \%$ of the plutonium and nearly $60 \%$ of the americium of the feed material. ${ }^{14}$ The incremental cost of recovering americium from the calcium metal concentrate was estimated by Larry Mullins (MST-13) to be $\$ 50 / \mathrm{g}{ }^{241} \mathrm{Am}^{15}$ The americium product could be prepared either as metal or oxide, with a chemical purity greater than $95 \%$. The value of the weapons-grade plutonium also recovered from the calcium button is $\$ 200 / 9$. $^{16}$

*Information provided by Tom Blum, Los Alamos National Laboratory, Los Alamos, N. Mex., August 18, 1983. 
Without considering the added benefit of the plutonium value, the pyrometallurgical process costs are less than $10 \%$ of the aqueous process costs for recovering americium and wouid probably result in a significantly lower selling price for the isotope. It should be noted that the incremental pyrometallurgical process cost estimates do not include capital costs, which would be necessary in a more detailed analysis. Special facilities would be required to undertake the recovery of plutonium from the MSE salts.

3. Discard Cost for ${ }^{241}$ Am. Because all newly generated transuranic waste at Los Alamos must be certifiable for disposal at WIPP starting in FY85, preparation and immobilization procedures for americium disposal outlined below take WIPP criteria into consideration. The disposal costs represent current operating expenses at Los Alamos for immobilization, certification, and preparation for transportation of transuranic waste. 17 The cost projections do not include transportation costs or WIPP handling charges.

The cost calculations assume that a pyrometallurgical process (see Sec. II.C.2 above) is used to recover plutonium from MSE residues. Two scenarios are considered: one in which the americium-containing calcium buttons are disposed of directly and the other in which americium is recovered.

If ${ }^{241} \mathrm{Am}$ is not to be recovered, the calcium buttons would be roasted to convert the metal to oxide. These oxide powders would then be immobilized in cement and packaged in 55-gallon drums suitable for shipment to WIPP. By assuming that the americium waste would be packaged to conform to the requirements for contact-handled transuranic wastes, a 7 imit of $16.44 \mathrm{~g} /$ drum can be established. ${ }^{17}$ Los Alamos costs of preparing a drum for disposal are estimated to be $\$ 5000 /$ drum. ${ }^{17}$ With the limit of $16.44 \mathrm{~g}$ of ${ }^{241} \mathrm{Am}$ per drum, the discard cost of ${ }^{241} \mathrm{Am}$ in the calcium buttons is approximately $\$ 300 / 9$.

If ${ }^{211}$ Am is recovered from the calciun. buttons by further processing, the americium recovery cost is estimated to be $\$ 50 / \mathrm{g}$ (see Sec. II.C.2 above). Assuming that $90 \%$ of the ${ }^{241} \mathrm{Am}$ is recovered from the calcium buttons, the discard cost of the unrecovered ${ }^{241} \mathrm{Am}$ is $\$ 33 / \mathrm{g}$. Therefore, the total cost of recovering the ${ }^{241} \mathrm{Am}$ and disposing of the resulting waste product is $\$ 85 / 9$. The differential cost between discard and recovery is $\$ 217 / \mathrm{g}$. Thus, it is significantiy more expensive to discard the ${ }^{241}$ Am from MSE residues than to recover it. 
Although this analysis assumes that a pyrometallurgical process is used to recover the plutonium and americium, the above disposal costs are also applicable to other methods of plutonium recovery. If ${ }^{241}$ Am is discarded in a sludge, the entrained ${ }^{241} \mathrm{Am}$ will contribute to whatever limit is used to determine the amount of sludge that can be contained in a drum. Thus, more drums will be necessary to dispose of the sludge than if the ${ }^{241}$ Am is not present, so there will be an additional disposal cost that can be charged to ${ }^{241}$ Am. This cost will probably not be radically different from the disposal costs found above.

\section{CONCLUSIONS}

Americium-241 is an exceedingly userul actinide isotope. Many applications have been developed or proposed, but most of these applications require very small quantities of the isotope, ranging from micrograms in smoke detectors to several grams in neutron sources. More than $99 \%$ of the ${ }^{241} \mathrm{Am}$ sold today in the US is destined for the manufacture of neutron sources used by the petroleum industry for well logging. Because of the current drop in petroleum exploration worldwide, the demand for ${ }^{241} \mathrm{Am}$ is depressed but is expected to recover in several years from the current slump. In the absence of new applications and new markets, however, ${ }^{241}$ Am's use is-not 1ikely to expand beyond the historical levels of about $2000 \mathrm{~g} / \mathrm{yr}$.

Because of renewed interest in a long-life power source that can be implanted in the body to power, for example, an artificial heart, we examined the reutronics and economics of producing very pure ${ }^{238} \mathrm{Pu}$ by irradiation of ${ }^{247} \mathrm{Am}$. We found that 97.2 atom peircent ${ }^{238} \mathrm{Pu}$ can be obtained by a 120 -day irradiation of ${ }^{241}$ Am followed by a two-step chemical separation--the first separation 4 weeks after jrradiation and the second separation after a 2-year decáy period. This "medical-grade" ${ }^{238} \mathrm{Pu}$ would cost approximately $\$ 21000 / \mathrm{g}$ to prepare, not including the initial cost of the ${ }^{241}$ Am.

Our evaluation of the physical and chemical properties of ${ }^{241}$ Am led us to conclude that ${ }^{241}$ Am should be considered for use as a heat source in smal1 RTGs of $1-5 \mathrm{~W}(\mathrm{e})$. First, ${ }^{241} \mathrm{Am}$ has two major advantages over ${ }^{90} \mathrm{Sr}$ and ${ }^{238} \mathrm{Pu}$, the two major RTG fuels used today. Americium-241 requires far less shielding than ${ }^{90} \mathrm{Sr}$ and unlike plutonium is not classified as a special nuclear material. Second, to be competitive with ${ }^{238} \mathrm{Pu}$ in terms of cost, the price of ${ }^{241}$ Am would have to fall from $\$ 7400 / g$ to $\$ 300 / g$; to be 
competitive with ${ }^{90} \mathrm{Sr}$, the price would have to fall even farther to approximately $\$ 42 / \mathrm{g}$. However, estimates for pyrometallurgical recovery of plutonium from the MSE residues at Rocky Flats indicate that ${ }^{241}$ Am could be recovered at a cost of $\$ 50 / \mathrm{g}$ (plus an additional cost of $\$ 33 / \mathrm{g}$ for waste disposal). Finally, the demand for RTGs is expected by many people associated with RTG production to increase dramatically in the next decade; several potential users of small RTGs were identified in the course of this project.

Finally, we deterinined that regardless of potential new appiications or increased demand for ${ }^{241} \mathrm{Am}$, the recovery and storage of a purified ${ }^{241} \mathrm{Am}$ product is móre economical than discarding ${ }^{241}$ Am as a waste product. Waste disposal costs were based on the new requirements that after FY84 transuranic wastes must be packaged for storage at WIPP and on the current WIPP requirements for contact-handled wastes. The americium-bearing waste product of the pyrometallurgical processing of MSE residues would cost approximately $\$ 300 / \mathrm{g}$ to discard, whereas recovery of the ${ }^{241} \mathrm{Am}$ from these wastes and disposal of the americium-bearing wastes of the recovery process would cost approximately $\$ 83 / \mathrm{g}$.

In sum, we concluded that potential new applications of ${ }^{241}$ Am in RTGs could stimulate demand for kilogram quantities of the isotope. Moreover, recovery of 241 Am from MSE residues at Rocky Flats is more economical than discarding $241 \mathrm{Am}$ as a transuranic waste.

\section{ACKNOWLEDGMENTS}

We would like to express our appreciation to T. R. England, W. B. Wilson, C. L. Fox, L. J. Mullins, W. A. Stark, Jr., and S. Bronisz at Los Alamos and to C. L. Ottinger at Oak Ridge, for their very gracious cooperation and assistance. Without their help and the benefit of their experience, our efforts would have been made far more difficult.

We would also like to thank T. K. Keenan for his constant support and assistance throughout the course of this project and wilma Bunker for her very conscientious editorial contribution.

\section{REFERENCES}

1. F. E. Levert and E. L. Helminski, "Literature Review and Commercia? Source Evaluation of Americium-241," prepared by the School of Engineering, Tuskegee Institute, Alabama, US Atomic Energy Commission report ORO-4333-1 (June 1, 1973). 
2. J. Lo Crandal1, "Applications of Transplutonitm Elements," Savannah River Laboratory report DP-MS-71-52 (September i 971 ).

3. "Key Uses Seen for Actinide Isotopes," Chemical and Engineering News 46, 54-55 (0ctober 14, 1968).

4. Salahuddin Shiekh and Albert P. Richter, "Nuclear Salt-in-Crude Monitor, "Journal of Petroleum Technology, 1009-1016 (May 1983).

5. H. T. McDuffee, V. C. A. Vaughen, F. A. Kappelmannn, and W. R. Whitson, "Recovery of Multigram Quantities of Curium-242 and Curium-244 in the Curium Recovery Facility," Oak Ridge National Laboratory report ORNL-4241 (December 1969).

6. V. C. A. Vaughen, W. T. McDuffee, E. Lamb, and R. A. Robinson, "The Preparation of Multigram Quantities of Curium-242 for SNAP-11," Nuclear Applications 6., 549-558 (June 1969).

7. T. R. England, W. B. Wilson, and M. G. Stamatelatos, "Fission Product Data for Thermal Reactors Part 2: User's Manual for EPRI-CINDER Code and Data," Electric Power Research Institute report EPRI-NP-356 (Dec 1976).

8. "ERTG Final Technical Report Appendices," Teledyne Isotopes report IESD-3112-1.2 (October 1973).

9. J. E. Hoisington, "Radioisotopes for Heat-Source Applications," Du Pont de Nemours, Savannah River $P$ ant memorandum DPST-82-842 (September 16, 1982--revised October 6, 1982).

10. "World Production of 0il Sinks to Lowest Volume in a Decade," 0 il and Gas Journal 81 (11), 23-26 (March 14, 1983).

11. "Deepwater Action S1 owed by Weak 0i] Prices, Uncertain Future," $0 i 1$ and Gas Journal 81 (15), 39-42 (Apri) 11, 1983).

12. Harold L. Davis, "Isotope Costs and Availability," Nucleonics 21 (3), 61 (March 1963).

13. R. F. Errington, "Commentary on Tons of Curium and Pounds of Californium," International Conference on Constructive Uses of Atomic Energy, Ruth Farmaker. Ed. (ANS, Hinsdale, Illinois, 1969) p. 204.

14. D. C. Christensen, "Proposal: Plutonium Recovery From Molten Salt Extraction Residues," Los Alamos National Laboratory memorandum MST-13-MPP-83-048 (March 1, 1983).

15. L. J. Mullins, "Cost Estimate for $241_{\text {Am }}$ Recovery from Calcium Metal Concentrate Resulting from Pyrometallurgical Recovery of Plutonium from Molten Salt Extraction (MSE) Residues," Los A] amos National Laboratory memorandum MST-13-GP0-83-126 (August 16, 1983). 
16. "Prices for Research Quantities of Actinide Isotopes," Oak Ridge National Laboratory isotope sales list, July 1, 1980.

17. C. L. Foxx, "Cost Estimate for Disposal of a Calcium Metal Concentrate Enriched in Americium-241, Resulting from Pyrochemical Recovery of Plutonium from Molten Salt Extraction (MSE) Residues," Los Al amos National Laboratory memorandum MST-12-PS-83-174 (October 26, 1983). 